\title{
PROPAGATION OF ANTIMICROBIAL RESISTANT Salmonella spp. IN BIVALVE MOLLUSKS FROM ESTUARY AREAS OF BAHIA, BRAZIL ${ }^{1}$
}

\author{
CARLA SILVA DA SILVEIRA ${ }^{2}$, OSCARINA VIANA DE SOUSA ${ }^{3}$, NORMA SUELY EVANGELISTA-BARRETO ${ }^{2 *}$
}

\begin{abstract}
In recent years, the emergence of resistant pathogens has complicated the treatment of bacterial infections in livestock production as well as in the medical field, due to the development of resistance mechanisms by microorganisms. The objective of this study was to delineate the antimicrobial resistance profile of Salmonella spp. strains isolated from bivalve mollusks (oysters and mussels) and from estuarine environment water of two regions of Bahia, Brazil. Twenty-seven strains, 12 isolated from bivalve mollusks and 15 from estuarine water, were tested. Eight antimicrobial agents (phenicol, beta-lactams, tetracyclines, quinolones and fluoroquinolones classes) were used for a susceptibility test, Minimum Inhibitory Concentration (MIC) and extended-spectrum beta-lactamases (ESBLs) production. Isolates showed high susceptibility to the classes of antimicrobial agents tested, with resistance only to nalidixic acid (27\%), ampicillin (25\%) and tetracycline (25\%). Bacterial resistance was of chromosomal origin and the multidrug resistance index (MAR) among isolates of shellfish (mussels in natura) was 0.25 . The MIC was found to be $100 \mu \mathrm{g} / \mathrm{mL}, 500 \mu \mathrm{g} / \mathrm{mL}$ and $350 \mu \mathrm{g} / \mathrm{mL}$ to nalidixic acid, ampicillin and tetracycline, respectively. None of the isolates presented ESBLs production. The presence of multidrug-resistant and high MIC Salmonella spp. is being conveyed in extraction areas of bivalve mollusks in the State of Bahia, Brazil.
\end{abstract}

Keywords: Antibiotics. Multidrug resistance. Food safety. Betalactamases.

\section{VEICULAÇÃO DE Salmonella spp. RESISTENTE A ANTIMICROBIANOS EM MOLUSCOS BIVALVES E EM ÁREAS ESTUARINAS, BAHIA, BRASIL}

\begin{abstract}
RESUMO - Nos últimos anos o surgimento de patógenos resistentes tem dificultado o tratamento de infecções bacterianas, tanto na produção animal como na área médica, em decorrência do desenvolvimento de mecanismos de resistência pelos micro-organismos. O objetivo deste estudo foi traçar o perfil de resistência antimicrobiana em cepas de Salmonella spp. isoladas de moluscos bivalves (ostras e sururu) e da agua de áreas estuarinas em duas regiões da Bahia, Brasil. Um total de 27 cepas previamente isoladas foram testadas, sendo 12 provenientes de moluscos bivalves e 15 de amostras de água. Para o teste de suscetibilidade foram utilizados oito agentes antimicrobianos (classes fenicóis, betalactâmicos, tetraciclina, quinolonas e fluoroquinolonas), Concentração Inibitória Mínima (CIM) e a produção de Betalactamases de Espectro Ampliado (ESBL). Os isolados apresentaram alta suscetibilidade as classes de antimicrobianos testadas, com resistência apenas ao ácido nalidíxico (27\%), ampicilina (25\%) e tetraciclina (25\%). A resistência bacteriana era de origem cromossômica e o índice de multirresistência (MAR) entre os isolados de molusco (sururu in natura) foi de 0,25. A CIM encontrada foi de $100 \mu \mathrm{g} / \mathrm{mL}, 500 \mu \mathrm{g} / \mathrm{mL}$ e $350 \mu \mathrm{g} / \mathrm{mL}$ para o ácido nalidixíco, ampicilina e tetraciclina, respectivamente. Nenhum dos isolados apresentou produção de ESBL. A presença de Salmonella spp. multirresistente e com elevada CIM está sendo veiculada em áreas de extração de moluscos bivalves no Estado da Bahia, Brasil.
\end{abstract}

Palavras-chave: Antibióticos. Multiresistência. Segurança dos alimentos. Betalactamases.

\footnotetext{
"Corresponding author

${ }^{1}$ Received for publication in $07 / 06 / 2014$; accepted in $01 / 27 / 2016$

Paper extracted from the master dissertation of the first author.

${ }^{2}$ Center for Agricultural, Environmental and Biological Sciences, Faculty of Fishing Engineering, Universidade Federal do Recôncavo da Bahia, Cruz das Almas, BA, Brazil; cal.silveira@yahoo.com.br, nsevangelista@yahoo.com.br.

${ }^{3}$ Sea Science Institute, Universidade Federal do Ceará, Fortaleza, CE, Brazil; oscarinasousa@yahoo.com.br.
} 


\section{INTRODUCTION}

Non-typhoid Salmonella is an important foodborne pathogen that can cause gastroenteritis and sepsis in humans. Food of animal origin play an important route of transmission of Salmonella and in humans infections are almost always result from the ingestion of food contaminated with bacteria (LAI et al., 2014).

In bivalve mollusks, whose feeding system is by filtration, high microbial load in tissues puts this food on a risk class for the consumer (AMAGLIANI et al., 2012), as they are very appreciated in natura.

Oysters are able to concentrate about three to 62 times more contaminants in their tissues than the environment where they are (MORRISON et al., 2011). Among the pathogenic microorganisms involved in environmental contamination, Salmonella spp. stands out for its wide distribution in nature, being able to be inserted into the aquatic environment through improper disposal of solid waste of human and/or animal origin (BUDIATI et al., 2013).

The genus Salmonella comprises more than 2,610 different serotypes (GUIBOURDENCHE et al., 2010). Salmonella enterica serovar Enteritidis has been the leading cause of outbreaks in many African, Asian, European and Latin American countries, being second most common serotype in North America and Oceania, representing $43.5 \%$ of all Salmonella isolates (CAMPIONI et al., 2012).

In Brazil, the incidence of diseases transmitted by seafood is not known, with few cases being reported because many etiologic agents cause mild symptoms and the victim does not seek medical assistance (SANTOS, 2010). However, there is evidence that the fish industry and its byproducts are on top of the list of foods associated with outbreaks of Foodborne Illnesses (Fi) (OLGUNOGLU, 2012). In the United States, the Fi have been responsible for about 76 million sick people every year, with the consumption of bivalve mollusks and other seafood accounting for $10-19 \%$ of cases (DIEGO et al., 2013).

In addition to the pathogenicity of Salmonella, several studies have warned about the emergence of strains resistant to several commercial antimicrobial (HUR et al., 2012) that spread through the food chain (FIGUEREIDO et al., 2013). The emergence of multidrug-resistant salmonella has been linked to the not always rational or judicious use of antimicrobial on the part of health workers, as well as the use of these drugs in aquaculture and livestock (POPPE et al., 2006).

The antimicrobial agents commonly used to treat infections caused by Salmonella are the ones from the class of fluoroquinolones and thirdgeneration cephalosporin (ASLAM et al., 2012). Among the various resistance mechanisms developed by Gram-negative bacteria is the enzymatic inactivation via the production of Extended Spectrum Beta-lactamases (ESBL), an enzyme that operates in the breakdown of the betalactam central ring, preventing the activity of the antimicrobial agents of this class, becoming one of the largest problems in the medical field, especially in the hospital setting (SANTOS, 2009).

Although there are few reports of ESBL associated with Salmonella when compared to other bacteria of the Enterobacteriaceae family, in some countries in Europe strains of ESBL-producing Salmonella have been isolated from food, environmental samples and wild animals (COQUE et al., 2008).

The significant seafood consumption in Bahia is due to the Bahian cuisine, especially in dishes such as moqueca (stew) and crab cake, besides the consumption of oysters in natura. In this context, it should be noted that the accumulation of pathogens resistant to commercial antibiotics in the tissues of bivalve mollusks tends to disseminate Salmonella to humans through the food chain, as a result of flaws in the infrastructure of coastal cities, such as lack of sanitation and management of solid waste produced by the community, most often launched at the margins of mangroves.

Given the above, the objective of this study was to investigate the antimicrobial resistance of Salmonella sp. isolated from bivalve mollusks in estuarine areas, in the cities of Valença and São Francisco do Conde, in face of different commercial antimicrobial and ESBL production capacity.

\section{MATERIAL AND METHODS}

Twenty-seven strains of Salmonella spp. were used, 12 strains from bivalve mollusks and 15 strains of estuarine water samples (Table 1). Strains were stored at $5^{\circ} \mathrm{C}$ in nutrient agar in the collection of the Laboratory of Food and Environmental Microbiology - LABMAA, at the Fisheries and Aquaculture Study Center - NEPA, of the Universidade Federal do Recôncavo da Bahia (Federal University of Recôncavo in Bahia) - UFRB. 
C. S. SILVEIRA et al.

Table 1. Salmonella spp. isolates, location and isolation source, in two regions of Bahia, Brazil.

\begin{tabular}{lcc}
\hline \multicolumn{1}{c}{ Code } & Location & Source \\
\hline F1, F2, F4, F5, F6 & SFC & Mussels in natura \\
F3, F7 & SFC & Oyster \\
F8, F9 & SFC & Processed mussels \\
F11, F12, F13 & Valença & Oyster \\
EW2, EW3 & Valença & Estuarine water \\
EW1, EW4, EW5, EW6, EW7, EW8, EW9, & & \\
EW10, EW11, EW12, EW13, EW14, EW15 & SFC & Estuarine water \\
\hline
\end{tabular}

F - food. EW - estuarine water. SFC - São Francisco do Conde.

The disk diffusion method described by the Clinical and Laboratory Standards Institute (CLSI, 2011) was used for antimicrobial susceptibility testing. Eight antimicrobial agents belonging to the classes of Betalactamics were selected: ampicillin AMP $(10 \mu \mathrm{g})$; cephalothin - CFL $(30 \mu \mathrm{g})$; imipenem - IMP $(10 \mu \mathrm{g})$ and ceftazidime - CAZ $(30 \mu \mathrm{g})$; Quinolones: nalidixic acid - NAL $(30 \mu \mathrm{g})$ and ciprofloxacin - CIP $(5 \mu \mathrm{g})$; Fenicol: chloramphenicol - CLO $(30 \mu \mathrm{g})$ and Tetracycline: Tetracycline - TET (30 $\mathrm{gg})$.

From cultures grown in tryptone soy agar (TSA) at $37^{\circ} \mathrm{C}$ for 24 hours, an inoculum was obtained with a concentration adjusted to standard 0.5 of the McFarland scale $\left(10^{7}-10^{8} \mathrm{CFU} / \mathrm{mL}\right)$. With the aid of a sterile swab, inoculum was spread on Mueller-Hinton agar plates. The disks with the antimicrobial agents were prepared at a distance from 20 to $25 \mathrm{~mm}$ apart, in order to avoid overlapping inhibition zones. The plates were incubated at $37^{\circ} \mathrm{C}$ for $18 / 24$ hours. The isolates were defined as sensitive, intermediate or resistant in accordance with the scanning range of the inhibition zone diameter for Enterobacteriaceae (CLSI, 2011).

The Multiple Antimicrobial Resistance index (MAR) was calculated and interpreted according to the formula: $\mathrm{a} / \mathrm{b}$, where a - number of antimicrobials to which the isolate showed resistance and $b$ - total number of antimicrobials to which the isolates were exposed (ADZITEY et al., 2012).

For strains that were resistant to antimicrobial agents, the minimum inhibitory concentration (MIC) was determined through the macrodilution in broth Mueller-Hinton technique (CLSI, 2011).

The strains which were resistant to at least one antimicrobial agent were subjected to the plasmid healing technique using Luria-Bertani (LB) broth and the orange mutagen acridine agent (AC) at a concentration of $100 \mu \mathrm{g} / \mathrm{mL}$. The strains were incubated in $\mathrm{LB}+\mathrm{AC}$ broth at $37^{\circ} \mathrm{C}$ for 24 hours and then again subjected to the antibiogram test in face of the antimicrobials against which they showed resistance (MOLINA-AJA et al., 2002).

The isolates that were resistant to antimicrobials of the beta-lactam class underwent ESBL detection by disk approximation test (CLSI, 2011). A plate containing Mueller-Hinton agar previously inoculated with the strain of interest $\left(10^{7}\right.$ $10^{8} \mathrm{CFU} / \mathrm{ml}$ ) was used for the test. An amoxicillin/ clavulanic acid disc was then placed in the center of the plate, and around it disks containing aztreonam $(30 \mu \mathrm{g})$, which served as markers at a distance of 20 $\mathrm{mm}$ from the central disc. The plates were incubated at $37^{\circ} \mathrm{C}$ for 18 hours and the formation of a synergy zone between the central disc and the antimicrobial marker was considered positive for the presence of ESBL.

\section{RESULTS AND DISCUSSION}

The increase in microbial resistance is a worldwide problem which has worsened in recent years. The cities of Valença and São Francisco do Conde, in Bahia state, present mangrove areas in their surroundings, which are very important for local fishery and population food chain. Anthropic actions as real estate speculation and improper sewage disposal in these regions have compromised food security of marine organisms when exposed to untreated waste, mainly bivalve mollusks which are filtering organisms and fresh consumed. This fact facilitates the colonization of resistant strains in individuals who often have not undergone treatment with antibiotics.

The susceptibility profile of Salmonella strains showed that most were sensitive to the tested antibiotics classes, with resistance only to ampicillin and tetracycline in isolates from mollusks and to nalidixic acid in isolates of estuarine water (Table 2). Isolates with intermediate resistance were observed only for nalidixic acid (Table 2).

The resistance to nalidixic acid, first generation quilonone, has increased in recent years. Nalidixic acid is an antimicrobial commonly used to treat urinary tract infections in humans and animals (CAMPIONI et al., 2012.), due to its effectiveness against most Enterobacteriaceae (SILVA; HOLLENBACH, 2010), but which has lost its effectiveness due to the increase of microbial resistance.

Strains that show this profile should be considered resistant, once the use of this antimicrobial triggers a process of resistant strains selection (CORTEZ et al., 2006). Carvalho et al. (2009), when testing 23 strains of Salmonella isolated from shrimp farms in Ceará, reported intermediate resistance to nalidixic acid and 
gentamicin in $4 \%$ of the isolates, suggesting the occurrence of cross-resistance among drugs.

When part of the residual charge of antimicrobials of human and animal use is released directly into surface waters and accumulates in the sediment, they alter the natural ecological balance, triggering an increase in resistant bacteria in the environment (REGITANO; LEAL, 2010). The presence of these compounds in the aquatic environment has drawn attention because it represents a risk to ecosystems, even when found in low concentrations, as antimicrobials are designed to inactivate or destroy microorganisms, having a significant impact on the processes controlled by indigenous biological communities (HUERTA et al., 2013).

Table 2. Antimicrobial susceptibility profile of Salmonella spp. strains derived from bivalve mollusks samples and estuarine waters to the different classes of antimicrobials tested in two regions of Bahia, Brazil.

\begin{tabular}{|c|c|c|c|c|c|c|c|c|c|c|c|c|}
\hline & \multicolumn{2}{|c|}{$\mathrm{S}$} & \multicolumn{2}{|c|}{ IR } & \multicolumn{2}{|c|}{$\mathrm{R}$} & \multicolumn{2}{|c|}{$\mathrm{S}$} & \multicolumn{2}{|c|}{ IR } & \multicolumn{2}{|c|}{$\mathrm{R}$} \\
\hline & $\mathrm{n}$ & $\%$ & $\mathrm{n}$ & $\%$ & $\mathrm{n}$ & $\%$ & $\mathrm{n}$ & $\%$ & $\mathrm{n}$ & $\%$ & $\mathrm{n}$ & $\%$ \\
\hline Beta-lactams & & & & & & & & & & & & \\
\hline - AMP & 9 & 75 & 0 & 0 & 3 & 25 & 15 & 100 & 0 & 0 & 0 & 0 \\
\hline - IMP & 12 & 100 & 0 & 0 & 0 & 0 & 15 & 100 & 0 & 0 & 0 & 0 \\
\hline - CFZ & 12 & 100 & 0 & 0 & 0 & 0 & 15 & 100 & 0 & 0 & 0 & 0 \\
\hline Tetracycline & & & & & & & & & & & & \\
\hline $\begin{array}{c}\text { - TET } \\
\text { Quinolones }\end{array}$ & 9 & 75 & 0 & 0 & 3 & 25 & 15 & 100 & 0 & 0 & 0 & 0 \\
\hline - NAL & 11 & 92 & 1 & 08 & 0 & 0 & 10 & 67 & 1 & 07 & 4 & 27 \\
\hline - CIP & 12 & 100 & 0 & 0 & 0 & 0 & 15 & 100 & 0 & 0 & 0 & 0 \\
\hline Fenicol & & & & & & & & & & & & \\
\hline $\begin{array}{l}\text { - CLO } \\
\text { Fluoroquinolones }\end{array}$ & 12 & 100 & 0 & 0 & 0 & 0 & 15 & 100 & 0 & 0 & 0 & 0 \\
\hline - CEF & 12 & 100 & 0 & 0 & 0 & 0 & 15 & 100 & 0 & 0 & 0 & 0 \\
\hline
\end{tabular}

AMP - ampicillin; IMP - imipenem; CFZ - ceftazidime; TET - tetracycline; NAL - nalidixic acid; CIP - ciprofloxacin;

CLO - chloramphenicol; CEF - cephalothin. S - sensitive; IR - intermediate resistance; R - resistant.

Resistance to tetracycline (25\%) (Table 2) is associated with the increased and excessive use of this antimicrobial in veterinary medicine, in the treatment or prophylaxis in aquaculture (CARNEIRO et al., 2007) and with being a second choice drug in the treatment of bacterial infections in human medicine (CONCEIÇÃO et al., 2007). The increased resistance to tetracycline is associated with the presence of resistance genes found on plasmids and by the acquisition and expression of efflux pumps, which reduce the toxic levels of the antimicrobial in bacterial cells (HUR et al., 2012).

The presence of resistant bacteria in the environment also occurs due to the final release of antimicrobial agents in water bodies, since part of the antimicrobial is absorbed by the organism and part excreted in urine. The lack of basic sanitation in the municipalities makes this waste reach rivers and estuaries (BILA; DEZOTTI, 2003). Another factor that contributes to this is the agricultural use of effluent or sludge as organic fertilizers, exposing the environmental microbiota to a range of antimicrobials of human and animal use (REGITANO; LEAL, 2010).

The observed resistance to ampicillin (25\%) (Table 2) is linked to the different resistance mechanisms developed by the microorganisms against the action of the drug. Among these, the bacteria's ability to hydrolyze the antimicrobials through the production of beta-lactamase enzymes, modification of penicillin binding proteins, the presence of efflux pumps or changes in cell membrane permeability (HUR et al., 2012). Since in this work isolates showed no production of betalactamase enzymes, it is suggested that the resistance observed is related to the anthropic pressure, since in the vicinity of the study area are several riverside communities.

Evangelista-Barreto et al. (2012), when studying strains of Escherichia coli isolated from fish in the municipal market of Cruz das Almas, Bahia, reported resistance to ampicillin in $12.5 \%$ $(1 / 8)$ of isolates. According to the authors, the routine use of this antimicrobial to treat infections in humans has contributed to drug resistance. Abhirosh et al. (2011), when analyzing the resistance profile of Salmonella isolated in freshwater in India, also reported resistance to ampicillin of $65.38 \%$ (17/26). According to the authors, the presence of multidrug resistant strains of Salmonella in fresh water is a health problem for the local population, since this bacterium is involved in outbreaks related to contaminated water consumption.

According to Table 3,33.3\% (9/27) of the isolates were resistant to at least one of the eight antimicrobials tested, with $04(14.8 \%)$ from the water of the São Francisco do Conde estuary and 03 $(11.1 \%)$ originated from the mussels in natura. Intermediate resistance to nalidixic acid was observed in $3.7 \%$ of the strains, with one strain from processed mussels (SFC), and one from the Valença estuary water. 
Strains originating from the water $(14.8 \%)$ and mussels in natura $(11.1 \%)$ from São Francisco do Conde showed higher antimicrobial resistance, probably due to the high contamination of fecal origin observed in the Subaé river (EVANGELISTA -BARRETO et al., 2013).

Table 3. Occurrence of resistance, multiple antimicrobial resistance (MAR) and plasmid resistance in Salmonella sp. strains isolated from bivalve mollusks and estuarine areas, in two regions of Bahia, Brazil.

\begin{tabular}{|c|c|c|c|c|c|c|}
\hline Location & Samples & $\mathrm{N}^{0}$ of isolates & Resistance & $\begin{array}{l}\text { Percentual of } \\
\text { resistance }\end{array}$ & MAR & $\begin{array}{l}\text { Plasmid } \\
\text { resistance }\end{array}$ \\
\hline \multirow{3}{*}{ SFC } & MIN & 3 & AMP, TET & 11.1 & 0.25 & NA \\
\hline & $\mathrm{PM}$ & 1 & NAL* & 03.7 & - & NA \\
\hline & EW & 4 & NAL & 14.8 & - & NA \\
\hline \multirow[t]{2}{*}{ Valença } & EW & 1 & NAL* & 03.7 & - & NA \\
\hline & & 9 & - & 33.3 & - & $0 \%$ \\
\hline
\end{tabular}

SFC - São Francisco do Conde. AMP - ampicillin, TET - tetracycline, NAL - nalidixic acid. EW - estuarine water. PM processed mussels. MIN - mussels in natura. *strains with intermediate resistance profile. NA - did not show resistance mediated by plasmid.

The multi-resistance profile (MAR 0.25) to the antimicrobial ampicillin and tetracycline (Table 3) was observed only in strains from mussels in natura, and this can be associated with the filtration process and bioaccumulation of microorganisms in animal tissue. The mussel is a mollusk that is buried in the sediment, and as antimicrobial residues accumulate in the sediment; this is subjected to a higher exposure as compared to the residue suspended in water.

The acquisition of resistance to antimicrobial agents of various classes (at least three) ensures the bacterial strain high survivability against different therapeutics, enabling the dissemination of these strains among animals, and humans and animals (FIGUEREIDO et al., 2013).

The municipality of São Francisco do Conde, the place that had isolates with higher resistance rate, has communities close to the estuary and, due to the lack of sanitation in the region; the waste from the households is dumped directly into estuaries. Another factor that may contribute to the presence of resistant bacteria is the raising of pigs and poultry in the backyards of residences, and the direct contact of the animals with the estuary, which favors the spread of pathogenic bacteria of animal origin to men. According to the local population accounts, factories located around the city also dump their waste directly into the estuary and this action can contribute to the ecological imbalance in the aquatic environment, affecting the production chain.

Resistance mediated by plasmids was not observed in any resistant strains (Table 3). The transfer of genes conferring chromosome resistance to bacteria occurs less frequently, thus having a smaller clinical impact when compared to plasmid resistance (EVANGELISTA-BARRETO et al., 2012). Chromosomal resistance depends on spontaneous mutation, which is infrequent and directed to single drug; however, sensitive bacteria can receive mutated chromosomal genes from bacteria already resistant through genetic recombination (VASCONCELOS et al., 2010). The chromosomal DNA is more stable, whereas the plasmid DNA is easily transferred from one line to another by bacterial conjugation (NEVES et al., 2007).

All isolates showed a high MIC to ampicillin, tetracycline and nalidixic acid. In the case of tetracycline resistance was 21.87 times greater than the limit established by the CLSI (2011), followed by ampicillin with 15.63 times and nalidixic acid with 3.2 times (Table 4 ).

Table 4. Minimum Inhibitory Concentration (MIC) of three antimicrobials of Salmonella spp., isolates of bivalve mollusks samples and estuarine water in two regions of Bahia, Brazil.

\begin{tabular}{ccccc}
\hline Code & Origin & \multicolumn{3}{c}{ MIC $(\mu \mathrm{g} / \mathrm{mL})$} \\
\hline F1 & & TET & AMP & NAL \\
F2 & Mollusks & 350 & 500 & - \\
F4 & Mollusks & 350 & 500 & - \\
F9 & Mollusks & 350 & 500 & - \\
EW3 & Mollusks & - & - & 100 \\
EW4 & EW & - & - & 100 \\
EW13 & EW & - & - & 100 \\
EW14 & EW & - & - & 100 \\
EW15 & EW & - & - & 100 \\
Standard CLSI (2011) & EW & $-16 \mu \mathrm{g} / \mathrm{mL}$ & $\geq 32 \mu \mathrm{g} / \mathrm{mL}$ & $\geq 32 \mu \mathrm{g} / \mathrm{mL}$ \\
\hline
\end{tabular}

AMP - ampicillin. TET - tetracycline. NAL - nalidixic acid. MIC - Minimum Inhibitory Concentration. EW - estuarine water. 
Bacteria from the Xiao river water, in China, showed MIC values of $128 \mu \mathrm{g} / \mathrm{mL}$ to $256 \mu \mathrm{g} / \mathrm{mL}$ to tetracycline and ampicillin, respectively (LI et al., 2010), values lower than those observed in this study

There are few studies reporting the MIC values for environmental bacteria in literature, and there is not a methodology standardization stipulating limits for aquatic bacteria, only for clinical strains. Several variation sources may interfere with the MIC values for a determined antimicrobial, such as the form of drug dilution, the type of culture medium used, the standardization of the bacterial inoculum and the incubation temperature (PEREIRA JÚNIOR et al., 2006).

None of the cultures tested positive for the production of ESBL. This fact may be related to the origin of isolates, since few studies have reported the presence of ESBL producing Salmonella in isolates of aquatic environment or food.

Microorganisms such as Aeromonas sp., Escherichia coli, Acinetobacter sp. and Pseudomonas sp. producers of ESBL were reported by Tacão et al. (2014) isolated from water samples in rivers from Portugal. Korzeniewska and Harnisz (2013), when analyzing water samples from a river which receives hospital sewage discharge, reported that $33.3 \%$ of the samples showed the presence of ESBL producing Enterobacteriaceae strains. In Rio de Janeiro, Brazil, strains of Klebsiella spp. Which produced ESBL from hospital effluents were also isolated (SILVA; LINCOPAN, 2012).

Another fact that has also contributed to the emergence of ESBL producing bacteria is livestock production. In Brazil, since 2003, strains of Salmonella spp. isolated from poultry slaughterhouses and resistant to cefotaxime have been considered potentially ESBL producing (JURE et al., 2010).

Salmonella is not a good ESBL producer, because unlike other Enterobacteriaceae, it requires a constitutive chromosome for the production of betalactamases. This fact affects the organism's biological maintenance, since the high expression level of these enzymes is incompatible with the bacteria intracellular invasion and multiplication (GARCIA et al., 2010).

Despite the fact that the incidence of ESBL producing bacteria is higher in the clinical area, it is important to carry out the monitoring of strains propagated in food and water due to the exchange of genetic material among the resistant strains and the microorganisms of the host or the environment microbiota (SILVA; LINCOPAN, 2012).

\section{CONCLUSION}

Salmonella strains propagated in bivalve mollusk extraction areas in Valença and São Francisco do Conde showed low resistance to commercial antimicrobials, without the production of ESBL. Salmonella spp. genus pathogenicity and strains resistant to antimicrobials of clinical use in environmental isolates serve as a warning to public health agencies for maintaining a continuous monitoring of the Enterobacteriaceae family pathogens, especially when transmitted to humans through the food chain.

\section{REFERENCES}

ABHIROSH, C. et al. Potential public health significance of faecal contamination and multidrugresistant Escherichia coli and Salmonella serotypes in a lake in India. Public Health, London, v. 125, n. 6, p. 377-379, 2011.

ADZITEY, F.; RUSUL, G.; HUDA, N. Prevalence and antibiotic resistance of Salmonella serovars in ducks, duck rearing and processing environments in Penang, Malaysia. Food Research International, Barking, v. 45, n. 2, p. 947-952, 2012.

AMAGLIANI, G.; BRANDI, G.; SCHIAVANO, G. F. Incidence and role of Salmonella in seafood safety. Food Research International, Barking, v. 45, n. 2, p. 780-788, 2012.

ASLAM, M. et al. Phenotypic and genetic characterization of antimicrobial resistance in Salmonella serovars isolated from retail meats in Alberta, Canada. Food Microbiology, London, v. 32, n. 1, p. 110-117, 2012.

BILA, D. M.; DEZOTTI, M. Fármacos no meio ambiente. Química Nova, São Paulo, v. 26, n. 4, p. 523-530, 2003.

BUDIATI, T. et al. Prevalence, antibiotic resistance and plasmid profiling of Salmonella in catfish (Clarias gariepinus) and tilapia (Tilapia mossambica) obtained from wet markets and ponds in Malaysia. Aquaculture: an international journal devoted to fundamental aquatic food resources, Amsterdam, v. 372-375, n. 1, p. 127-132, 2013.

CAMPIONI, F.; BERGAMINI, A. M. M.; FALCÃO, J. P. Genetic diversity, virulence genes and antimicrobial resistance of Salmonella Enteritidis isolated from food and humans over a 24year period in Brazil. Food Microbiology, London, v. 32, n. 2, p. 254-264, 2012.

CARNEIRO, D. O. et al. Perfil de susceptibilidade a antimicrobianos de bactérias isoladas em diferentes sistemas de cultivo de tilápia-do-nilo (Oreochromis niloticus). Arquivo Brasileiro de Medicina 
Veterinária e Zootecnia, Belo Horizonte, v. 59, n. 4, p. 869-876, 2007.

CARVALHO, F. C. T. et al. Susceptibilidade antimicrobiana de Salmonella spp. isoladas de fazendas de carciniculturas no Estado do Ceará. Revista Ciência Agronômica, Fortaleza, v. 40, n. 4, p. 549-556, 2009.

CLINICAL AND LABORATORY STANDARDS INSTITUTE, CLSI, Performance Standards for Antimicrobial Susceptibility Testing, TwentyFirst Informational Supplement. CLSI document M100-S25. Clinical and Laboratory Standards Institute, Wayne, PA. v. 35, n. 3, 2011.

CONCEIÇÃO, R. C. S. et al. Isolamento de Salmonella de produtos de frango e perfil de suscetibilidade dos isolados a antimicrobianos. Revista do Instituto Adolfo Lutz, São Paulo, v. 66, n. 1, p 31-34, 2007.

COQUE, T. M.; BAQUERO, F.; CANTON, R. Increasing prevalence of ESBL-producing Enterobacteriacea in Europe. Euro Surveillance, Stockholm, v. 13, n. 47, p. 1-11, 2008.

CORTEZ, A. L. L. et al. Resistência antimicrobiana de cepas de Salmonella spp. isoladas de abatedouros de aves. Arquivos do Instituto Biológico, São Paulo, v. 73, n. 2, p. 157-163, 2006.

DIEGO, A. G. L. et al. Sanitary quality of edible bivalve mollusks in Southeastern Brazil using an UV based depuration system. Ocean \& Coastal Management, Newark, v. 72, n. 1, p. 93-100, 2013.

EVANGELISTA-BARRETO, N. S. et al. Avaliação das condições higiênico-sanitárias do pescado comercializado no município de Cruz das Almas, Bahia. Revista Caatinga, Mossoró, v. 25, n. 3, p. 86 $-95,2012$.

EVANGELISTA-BARRETO, N. S. et al. Avaliação do impacto ambiental no rio Subaé, São Francisco do Conde-BA, através de bioindicadores de contaminação fecal. Magistra, Cruz das Almas, v. 25, n. 2, p. 164-169, 2013.

FIGUEIREDO, R. et al. Resistencia a antibióticos em isolados de Salmonella entérica em alimentos de origem animal. Revista Portuguesa de Ciências Veterinárias, Lisboa, v. 108, n. 585-586, p. 39-43, 2013.

GARCÍA, C. S.; GÁNDARA, M. P.; GARCÍA, F. J. C. Betalactamasas de espectro extendido en enterobacterias distintas de Escherichia coli y Klebsiella. Enfermedades Infecciosas y
Microbiología Clínica, Madrid, v. 28, n. 1, p. 12-18, 2010 .

GUIBOURDENCHE, M. et al. Supplement 2003 e 2007 (No. 47) to the White-Kauffmann-Le Minor scheme. Research in Microbiology, Paris, v. 161, n. 1, p. 26-29, 2010.

HUERTA, B. et al. Exploring the links between antibiotic occurrence, antibiotic resistance, and bacterial communities in water supply reservoirs. Science of the Total Environmental, Amsterdam, v. 456-457, n. 1, p. 161-170, 2013.

HUR, J.; JAWALE, C.; LEE, J. H. Antimicrobial resistance of Salmonella isolated from food animals: A review. Food Research International, Barking, v. 45 , n. 2 , p. $819-830,2012$.

JURE, M. A. et al. Extended-spectrum $\beta$-lactamaseproducing Salmonella enterica serovar Oranienburg (CTX-M-2 group) in a pediatric hospital in Tucumán, Argentina. Revista da Sociedade Brasileira de Medicina Tropical, Rio de Janeiro, v. 43, n. 2, p. 121-124, 2010.

KORZENIEWSKA, E.; HARNISZ, M. Extendedspectrum beta-lactamase (ESBL)-positive Enterobacteriaceae in municipal sewage and their emission to the environment. Journal of Environmental Management, London, v. 128, n. 1, p. 904-911, 2013.

LAI, J. et al. Serotype distribution and antibiotic resistance of Salmonella in food-producing animals in Shandog province of China, 2009 and 2012. International Journal of Food Microbiology, Amsterdam, v. 180, n. 1, p. 30-38, 2014.

LI, D. et al. Antibiotic resistance characteristics of environmental bacteria from an oxytetracycline production wastewater treatment plant and the receiving river. Applied and Environmental Microbiology, Washington, v. 76, n. 11, p. 3444 3451,2010

MOLINA-AJA, A. et al. Plasmid profiling and antibiotic resistance of Vibrio strains isolated from cultured penaeid shrimp. FEMS Microbiology Letters, Amsterdam, v. 213, n. 1, p. 7-12, 2002.

MORRISON, C. M. et al. Survival of Salmonella Newport in oysters. International Journal of Food Microbiology, Amsterdam, v. 148, n. 2, p. 93-98, 2011.

NEVES, M. C. et al. Detecção de genes de resistência antimicrobiana em cromossomos e plasmídeos de Staphylococcus spp. Arquivos do 
Instituto Biológico, São Paulo, v. 74, n. 3, p. 207213, 2007.

OLGUNOGLU, İ. A. Salmonella in Fish and Fishery Products. In: Salmonella - A Dangerous Foodborne Pathoge. p. 91-105. 2012. Disponível em: < http:// cdn.intechopen.com/pdfs/26424.pdf $>$. Acesso em: 20 jun. 2014.

PEREIRA JÚNIOR, D. J. et al. Concentração inibitória mínima de oxitetraciclina para isolados de Aeromonas hydrophila obtidos de diferentes fontes. Ciência e Agrotecnologia, Lavras, v. 30, n. 6, p. 1190-1195, 2006.

POPPE, C. et al. Characterization of antimicrobial resistance of Salmonella Newport isolated from animals, the environment, and animal, food products in Canada. Canadian Journal of Veterinary Research, Ottawa, v. 70, n. 2, p. 105-114, 2006.

REGITANO, J. B.; LEAL, R. M. P. Comportamento e impacto ambiental de antibióticos usados na produção animal brasileira. Revista Brasileira de Ciência do Solo, Campinas, v. 34, n. 3, p. 601-616, 2010.

SANTOS, S. B. Incidência de Enterobactérias produtoras de Betalactamase de Espectro Estendido (ESBL) em um Hospital do Município de Duque de Caxias-RJ. Revista Brasileira de Análises Clínicas, Rio de Janeiro, v. 41, n. 4, p. 251-255, 2009.

SANTOS, C. A. M. L. Doenças transmitidas por pescado no Brasil. Revista Brasileira de Medicina Veterinária, Rio de Janeiro, v. 32, v. 4, p. 234-241, 2010 .

SILVA, K. C.; LINCOPAN, N. Epidemiologia das betalactamases de espectro estendido no Brasil: impacto clínico e implicações para o agronegócio. Jornal Brasileiro de Patologia e Medicina Laboratorial, Rio de Janeiro, v. 48, n. 2, p. 91-99, 2012.

SIlVA, J. M. B.; HOLLENBACH, C. B. Fluoroquinolonas $\mathrm{X}$ Resistência bacteriana na medicina veterinária. Arquivos do Instituto Biológico, São Paulo, v. 77, n. 2, p. 363-369, 2010.

SOUZA, R. B. et al. Ciprofloxacin susceptibility reduction of Salmonella strains isolated from outbreaks. Brazilian Journal of Microbiology, São Paulo, v. 41, n. 2, p. 497-500, 2010.

TACÃO, M. et al. Co-resistance to different classes of antibiotics among ESBL - producers from aquatic systems. Water Research, New York, v. 48, n. 1, p. 100-107, 2014.
VASCONCELOS, F. R. et al. Perfil de resistência antimicrobiana de Escherichia coli isoladas do açude Santo Anastácio, Ceará, Brasil. Arquivos do Instituto Biológico, São Paulo, v. 77, n. 3, p. 405410, 2010. 